\title{
The Intercultural Reconstruction of Guarani School Linguistic Human Rights: Social Purviews and Literacy ${ }^{1}$
}

\author{
Carlos Maroto Guerola
}

\begin{abstract}
This paper seeks to contribute to the intercultural reconstruction of the school linguistic human right to literacy ${ }^{2}$. It questions the monoglossic and universalizing nature with which that right is inserted in the social purview of the dominant groups of global capitalism. Based on a theoretical framework that articulates discourses from Applied Linguistics, Cultural Studies, the Bakhtin Circle, and the New Literacy Studies, in my data analysis I interpret discourses on this concern by the Guarani teachers of the Itaty Indigenous Primary School, located in the Guarani village of Morro dos Cavalos, Santa Catarina, Brazil. Those teachers interculturally reconstruct the right to literacy as the right of the school to safeguard Guarani cultural tradition (claimed upon transformations of the community's forms of utterance and legitimated practices of knowledge generation and transmission which are brought about by transformations in their economy). This right is also reconstructed as a "weapon of defense and survival" with which to struggle for fuller sovereignty over their forms of utterance and, inseparably, over their economy.
\end{abstract}

Keywords: speech-literacy; Indigenous school; linguistic rights

\section{The Intercultural Reconstruction of School Linguistic Human Rights}

Indigenous protests and demonstrations all over Brazil-recently instanced by examples such as the Indigenous National Mobilization or Indigenous April (Abril Indígena) (APIB, 2012; CIMI, 2012)-are living threads of the intense and vivid web of articulations in the struggle over Indigenous rights and causes. They illustrate the

\footnotetext{
1 This text was previously presented at the Fifth International Symposium on Bilingualism and Bilingual Education in Latin America in Valparaíso, Chile, in October 2013; it was published in Portuguese in the Brazilian journal Trabalhos em Linguística Aplicada in July 2014. The Portuguese version of this text can be retrieved from http://dx.doi.org/10.1590/S0103-18132014000100012. English translation by Carlos Maroto Guerola. All quotes originally in languages other than English have also been translated by the author/translator of this text.

2 When making reference to 'school linguistic human rights', the word 'school' is used as an adjective (such as, for example, in 'school uniform' or 'children of school age'). 'School' is used instead of the word "educational", once Guarani teachers and leaders always emphasize that "Indigenous education" (educação indígena) and "Indigenous school education" (educação escolar indígena) are not synonyms and, hence, should never be confused. Therefore, I avoid using 'educational' to make reference to the linguistic human rights concerning schooling.
} 
never-ending battle that these peoples have been waging against the violence of the economic and political projects through which capitalism has taken shape in Brazil for centuries. These projects (called neoliberal these days) seek to accelerate growth and development at the same costs of exclusion and violence of those preceding them.

Many of these enterprises today mean a dire threat against rights that were recognized for Brazilian Indigenous groups for the first time only in the 1988 Federal Constitution. These projects mean a threat particularly against the rights that concern "social organization, customs, languages, creeds, and traditions recognized, as well as [...] the lands they traditionally occupy" (Brasil, 1988/2010, pp. 152-153). Furthermore, they have resulted in the large-scale violence-both symbolic and physical-that many Indigenous communities are forced to face in the daily life of their villages, both in rural and urban contexts.

Within this conjuncture, the master's thesis There Are Some People Who Do Not Even Think of Listening, Who Give Indians No Right to Speak (Guerola, 2012), which was based on ethnographic research, sought to contribute to the intercultural reconstruction of the school linguistic human rights of the Guarani community of Morro dos Cavalos, which is located in the city of Palhoça, in the Greater Florianópolis area (Santa Catarina, Brazil). For that purpose, Guerola (2012) researched the language practices that community demands for its school, as well as how those practices are intertwined with the political and economic context that makes them indispensable to the extent of being demanded as school linguistic human rights.

That research was grounded on Sousa Santos's (2002) questions on the alleged universalism of the human rights concept and politics, for they were established upon a "well-known set of presuppositions, all of which are distinctly Western" (p. 44). It is on these grounds that Sousa Santos (2002) puts forward the intercultural reconstruction of human rights. For this author, "cross-cultural dialogues on isomorphic concerns" (p. 46), which cast light on traditionally silenced perspectives, may give birth to rights with "global competence and local legitimacy" (p. 44). These features represent, for Sousa Santos, "the two attributes of a counterhegemonic human rights politics in our time" (p. 44).

Thanks to the words and help of the Guarani teachers who collaborated in the research, ${ }^{3}$ the approach to the intercultural reconstruction of linguistic human rights in Guerola (2012) questioned allegedly universal rights, such as schooling or literacy. He points out that these rights are universal only as human duties (bound to capitalist political and economic projects), and that they are actually human rights in the sense that people appropriate those duties and use them as weapons to struggle with when interculturally reconstructed, many times against those duties bound to them. For example, school education is compulsory for all Brazilian

3 I would like to heartily thank the teachers and Guarani leaders Marcos Moreira, Eunice Antunes, Adão Antunes, João Batista Gonçalves, and Joana Mongelo, for their great assistance and meaningful participation in this research. All of them authorized the use of their real names for academic purposes. 
citizens of school age according to their Constitution (as it is in many other countries). It is also compulsory because it is harsh (if not impossible) to earn a living (and economically survive) in that country for someone without schooling. It is in this sense that schooling is a universal human duty. Guarani people, nonetheless, are taking advantage of this duty by interculturally reconstructing it and transforming it in a way to better prepare themselves to struggle for their rights, for example, their right for an Indigenous schooling or their right to have their lands officially demarcated.

Because of this, Guerola (2012) suggests a notion of rights that is closely tied to duties and needs: Within the previously described conjuncture, the violence that most Indigenous communities are forced to face every day-fostered by some elites and lobbies willing to exploit Indigenous lands-prevents them from being able to satisfy their needs and to survive autonomously. Because they are dispossessed of their resources and of the viability of their self-sufficiency, those communities remain tightly locked inside an economic, political, and cultural system that is imposed on them as the only available alternative. It is within such a context of conflicts and violence that denying, demanding, and/or acknowledging rights by some groups in relation to others elicit the "ideological semiotic reaction" (Voloshinov, 1929/1986, p. 22) that assigns meaning to those actions and to the signs that represent them.

Thus, the Guarani people of Morro dos Cavalos currently demand school linguistic human rights such as the right to voice, visibility, and legitimacy, the right to a cross-cultural exchange of knowledge, to (bi)literacy, and to "differential" Guarani schooling, among others. They clamor mainly for land, for this is the key to a fuller sovereignty that makes it easier to guarantee their own rights (whether linguistic or not) by themselves. It is important to note that all of these demands arise from the needs created by the system that harasses them. Both school and literacy are today, for most Guarani people, a need (they need them to survive), a duty (the State and the Law impose them as such), and a right (Guarani people demand them as rights as they are essential to the satisfaction of their needs).Extracted from Guerola (2012), this paper aims to question the monoglossic nature assigned to the right to literacy as inserted within dominant social purviews. ${ }^{4}$ It seeks, moreover, to contribute to the intercultural reconstruction of that right by academically enhancing the visibility of the voices and discourses on the subject of Itaty School Guarani teachers. The following section establishes a dialogue among some discourses of Applied Linguistics, Cultural Studies, the Bakhtin Circle, and the New Literacy Studies. This dialogue is established in order to shed light on the interpretation of the discourses by the Guarani teachers playing the lead in the data analysis section. They interculturally reconstruct the human right to literacy, firstly, as the right to the school record of the Guarani cultural tradition that is demanded as a result of economy-based transformations of community forms of utterance and the practices of knowledge creation and

\footnotetext{
${ }^{4}$ For Voloshinov (1986), a social or evaluative purview is "all those things that have meaning and importance for a particular group" (p. 106).
} 
transmission that they consider legitimate. Secondly, the right to literacy is reconstructed as a "weapon for defense and survival," in the words of chief Eunice Antunes. In this sense, Guarani intercultural rights emerge as viable weapons, as acceptable dissidence according to modernity's own objectives (Mignolo, 2004).

\section{Hierarchy, Bases of Material Life and Literacy}

For the Bakhtin Circle's philosophy of language, there is an organic relationship between language, ideology, and socioeconomic relations. Once the full range of verbal contacts, forms, and means of verbal communication are determined by the relations of production and the sociopolitical order, changes in economic relations result in changes in the forms of utterance. Those transformations also modify ideology, once the domain of ideology corresponds to the domains of discourse, utterance, and signs (Voloshinov, 1929/1986).

The rigid hierarchy of capitalist socioeconomic relations and political order exerts an enormous influence over the forms of utterance, as well as over the social evaluative purview of particular social groups:

The generative process of signification in language is always associated with the generation of the evaluative purview of a particular social group, and the generation of an evaluative purview -in the sense of the totality of all those things that have meaning and importance for the particular group-is entirely determined by expansion of the economic base. (Voloshinov, 1929/1986, p. 106)

For an object to elicit the "ideological semiotic reaction" that creates a sign, therefore, it is essential that it "somehow, even if only obliquely, makes contact with the bases of the group's material life" (Voloshinov, 1929/1986, p. 22). The economy patterns social evaluative purviews, that is, "all those things that have meaning and importance" in the eyes of each and every social group. Those purviews lead, for their part, to the "generative process of signification in language" (Voloshinov, $1929 / 1986$, p. 106). It is upon the dialogic relationship between language, ideology, and economy that social groups insert literacy and its forms of utterance in their social evaluative purviews.

Heath and Street (2008) suggest a definition of culture as metanarratives through which social groups make sense of their particular history, habits, and behaviors. It is only through such a semiotic definition of culture that it becomes possible to begin discerning possible links between this concept and Voloshinov's (1929/1986) concept of social evaluative purview. In this regard, it is worth pointing out the dialogic threads that stitch the evaluative purview of capitalist dominant groups to the metanarrative of modernity (Lander, 2005). This metanarrative encompasses discourses that represent the Western and modern model of civilization as the most developed one, and hence, superior within an evolutionary scale that subordinates those groups underprivileged by global relations of production and socioeconomic structures. By doing that, dominant groups establish a "radically exclusive universalism" (Lander, 2005) that proscribes 
social groups by labeling them either as irrelevant, incomprehensible, or noncredible alternatives to what already exists (Sousa Santos, 2010).

The asymmetry between the symbolic control of the evaluative purview of the groups at the top of the capitalist socioeconomic hierarchy and the delegitimization of that of the groups at its base is supported by the capacity that "socially significant world views" have to exploit the "intentional possibilities of language." Those views, through their metanarratives, "attract its words and forms into their orbit by means of their own characteristic intentions and accents, and in so doing to a certain extent alienate these words and forms from other tendencies, parties, artistic works, and persons" (Bakhtin, 1981, all quotes p. 290).

It is the exploitation of the intentional possibilities of words and forms of utterance that best instantiates the ideological clashes inside the network of signs, discourses, and meanings of social heteroglossia. In Bakhtin's eyes, discourse is constituted by a heteroglossic internal dialogism that is progressively made monoglossic with the help of "centripetal forces" (Bakhtin, 1981, p. 425). Those forces reduce the internal plurality of signs and discourses to exclusive meanings that serve a particular evaluative purview. After all, different social classes use the same language and, therefore, in every single ideological sign there is a clash of conflicting value judgments or accents. Dominant classes seek to make signs monoglossic, with meanings beyond class differences, to be able to conceal the clash of accents that takes place inside them (Voloshinov, 1929/1986).

Both the signs and discourses that represent the interactions and practices mediated by written forms of utterance have fallen under the influence of centripetal forces throughout history. Those forces silence the clash of value accents that occurs inside those semiotic elements. That is what happened, for instance, through the exclusion of the meanings that those signs have for Indigenous peoples. In this sense, Franchetto (2008) declares that, despite the impact of writing (alongside its corollaries, literacy and schooling) being among the most indelible experiences in the history of the relationship between Indians and non-Indians, almost nothing has been heard from what Indigenous groups in Brazil have to say about literacy.

As a result of this exclusion, the contrast and polarization between orality and literacy have favored discourses related to the metanarrative of modernity, and hence, the interests of the groups that determine the dominant social purview. In these exclusive discourses, literacy has been defended as a civilizing good, inextricably bound to the "vital needs of modern and developed individuals and societies" (Galvão \& Batista, 2006, p. 424). That allegedly evolutionary breakthrough categorizes human beings in "two species, cognitively distinct: those that can read and write and those that cannot" (Kleiman, 1995, p. 27). Within this paradigm, writing has not only been overvalued but also judged essential to the fulfillment of the fullest human potential (Ong, 1982, as cited in Gee, 1994). Furthemore, writing has been considered as the only valid system to demonstrate the human capacity for abstraction (Galvão \& Batista, 2006). 
The New Literacy Studies, on the other hand, identify those representations with the privilege of Western ideas about literacy over those of other cultures, or, within the same country, of one social class over others (Street, 2003). The distinction orality-literacy contrasts, after all, diverse cultural practices that, in different contexts, require distinct uses of language (Gee, 1994). And if social practices dialogically link discourse to the material activities, social relations, and beliefs, values, and desires of the agents and communities involved in them (Chouliaraki \& Fairclough, 1999), the polarization of oral and literate practices, to the subsequent detriment of the former, leads to the delegitimization of the material activities, social relations, beliefs, desires, and values of those who grant higher legitimacy to oral forms of utterance.

Such disdain is tied, as noted earlier, to the hierarchization of the socioeconomic structures of capitalism in its current neoliberal version. In this sense, César and Cavalcanti (2007) question how, progressively,

[d]iscourses about the universalization of education grow stronger, as do discourses about almost mandatory digital literacy and the eradication of illiteracy-seen as a disease, one that needs to be eradicated-among others. It seems that the more totalitarian and exclusive the model becomes, the more insistently the discourse of the need for inclusion is vindicated. What kind of inclusion? To reaffirm dominant political projects and ideologies? (p. 51)

It is worth illustrating Cesar and Cavalcanti's (2007) questioning of the universalization of education and the eradication of illiteracy, through the celebrated words of the founder of the Summer Institute of Linguistics, the academic-religious institution that has dominated the research and production of grammars and dictionaries of Amerindian languages since the 1930s. The following quote exemplifies the link established by the missionary Cameron Townsend between the initiation of Indians into reading practices and the awakening of their interest in the purchase of manufactured products:

Once they can read, even when initially only in their native language, [Indians] lose their inferiority complex. They become interested in new things. They get interested in buying manufactured articles - implements, mills, clothing, etc. To buy such things, they need to work more. Production grows, and so, eventually, does consumption. All of society, apart from the barman and the wizard, gains some benefit. The Indian is found to be worthier as a cultured man than as an uneducated one sunk in ignorance. (Townsend, 1949 as cited in Barros, 1994, p. 25)

In line with this, the anthropologist Claude Levi-Strauss (1957), highlights the authoritarianism of the universalism with which the right to reading and writing has been traditionally represented. Levi-Strauss links the systematic action since the 19th century of European countries in favor of mandatory universal education to the spread of military service and proletarianization. The fight against illiteracy 
would be related to the submission of larger population contingents to the capitalist system and its laws. Thus, from Levi-Strauss's point of view, because of allowing and naturalizing the submission of thousands of workers to exhausting jobs in exchange for a salary, written communication favors the exploitation of men rather than their enlightenment. It is in this sense that, according to him, the primary function of writing is to facilitate servitude (as cited by Meliá, 1979, p. 57).

At this point, the relationship between signs, forms of utterance, discourses, and evaluative purviews has been theoretically grounded; the dialogic threads between the dominant social purview and the metanarrative of modernity have been tied; and the polarization between orality and literacy has been identified as a strategy for delegitimizing the material activities, social relations, beliefs, values, and desires of certain social groups. So I shall now move on to the section of data analysis. In the following section, the clash between the discourses of the Guarani teachers of Itaty School and the relations of production and sociopolitical structure that exploit certain intentional possibilities of the signs and discourses related to literacy is illustrated.

\section{"We need to leave everything written at school because the elderly do not exist culturally any more": Literacy in the Guarani's social purview}

As part of their traditional territory, Guarani Indians have occupied the coast of what is today Santa Catarina since at least the beginning of the second millennium (Litaiff \& Darella, 2000). However, this is not at all the discourse conveyed by the individuals, groups, and media against the demarcation of Indigenous lands in Brazil. Indeed, some of them have aggressively campaigned against the homologation of the Indigenous Land of Morro dos Cavalos, whose demarcation process became two decades old in 2013 (Guarani Community et al., 2012). The wait is an anxious one for the Guarani, once only the relocation of the Non-Indigenous land-dwellers still living in the demarcated area to non-demarcated areas will warrant the Guarani of Morro dos Cavalos-quoting article 231 of Brazilian Federal Constitution-the land that is "indispensable to the preservation of the environmental resources necessary for their well-being and for their physical and cultural reproduction, according to their uses, customs and traditions" (Brasil, 1988/2010, p. 153).

While awaiting the guarantee of the rights to their own land, the Guarani lack sovereignty and economic self-sufficiency. For this reason, they are dependent on the dominant society, the Brazilian State and the globalized neoliberal market economy. Their current means of support are making and selling craftwork, wagelabor jobs, scholarships for study and research, government conditional cashtransfer programs and sporadic farming and cattle breeding. It was as a result of their harsh living conditions and of the dependence on Non-Indigenous society and their commodities that in the 1990s, alongside the demarcation of specific areas to survive and exist, the Guarani started demanding schools for their communities (Vieira, 2006). 
It was in that decade that Itaty Indigenous School was inaugurated in the Guarani village of Morro dos Cavalos. Located immediately next to the edge of BR101 , the main Brazilian highway, the school hosts countless events that take place in the village. Protests, manifestos, official letters, prayers, lessons, etc., are some of the usual discursive genres and practices at Itaty School. The discourses bound to them constitute a unique sample of the silenced social heteroglossia that is voiced there.

At their school, the Guarani of Morro dos Cavalos reinterpret and interculturally reconstruct rights, signs, and forms of utterance. Despite the fact that many of those rights (such as the right to school or the right to literacy) were originally imposed on them as needs by the groups and systems that still harass them, the Guarani appropriate and use those rights as weapons for defense and survival in favor of the economic and political objectives of their evaluative purview. It is in this sense that universal duties (such as elementary instruction, compulsory according to both the Universal Declaration of Human Rights and the Brazilian Federal Constitution) are reconstructed as intercultural human rights by the Guarani.

That reconstruction, however, encounters obstacles in the monoglossic nature with which some signs and forms of utterance were universally constructed by traditional schooling. In this sense, during my first weeks of fieldwork, ${ }^{5}$ collaborators insistently mentioned how easily their students learn through orality and the difficulties they run into when they need to learn theoretically, through writing. In my classroom observations, I actually started noticing how central reading and writing were in daily classroom activities. When I decided to inquire about this matter, the answers started revealing the link between the community's forms of utterance and their social purviews, economic practices and bases of material life: 6

Antigamente [...] toda criança tinha que ficar na Casa de Reza, aprendendo, era... o ensinamento era passado na oralidade mas ele era praticado, você chegava assim, a criança ali falava assim "Ô, eu quero pescar, eu quero aprender a pescar". O vô, o tio, o pai chamava [...] o filho e ele sentava ali e ele passava todos os conhecimentos oralmente, depois ele pegava e falava "agora vamo pescar". Então quando o filho chegasse lá no rio, tudo aquilo que o pai tinha passado ele ia praticando e aprendendo, então é assim que ele aprendia, com tudo, na agricultura, mesma coisa [...] era toda a questão religiosa e tudo, envolvia tudo [...] Quando os europeus invadiram, começaram a catequizar, eles tiraram, tiraram a criança da Casa de Reza, do dia a dia dele, do aprendizado dele e trouxeram pra escola, a criança começou a perder os

\footnotetext{
5 The research that led to the dissertation from which this paper is excerpted was carried out between 2011 and 2012, using a qualitative and ethnographic approach based on participant observation of lessons and the daily life of the school, as well as on the recording of semistructured interviews with the Indigenous teachers of the institution.

${ }^{6}$ Fully conscious of the impossibility of a faithful translation that conveys in English the equivalent social meanings conveyed in the Portuguese originals, I decided to keep the original utterances of the Guarani teachers in Portuguese so that the translations could be fairly literal and could be easily compared to the originals.
} 
ensinamentos, começou a ficar sentado ali aprendendo a ler e escrever [...] ai deu-se um conflito, claro né, e dai a criança já não tava aprendendo aquilo que era pra ser né, que era pra ele aprender, e hoje né, hoje a gente já... aqui não tem como eu tar passando na oralidade. (Interview with Eunice Antunes, 07/11/2011)

In the old days [...] every child had to stay in the House of Prayer, learning, it was ... all learning was passed on orally but it was practiced [...] the kid would say "I want to fish, I want to learn how to fish." The grandfather, the uncle, the father would then call [...] the-kid and sit down and pass on all knowledge orally, and then he would say, "Now let's go fish." So by the time the son got to the river, he was practicing and learning everything his father had passed on, this was how he used to learn everything, the same thing with farming [...] it involved all the religious matters, absolutely everything [...] When the Europeans invaded, they started to catechize, they pulled the children out of the House of Prayer, out of their everyday life, and brought them to school, the children started to lose the teachings, they started to remain seated just learning how to read and write [...] there was a conflict and the child was no longer learning what needed to be learned, and today, today we don't ... here it's impossible to pass on [teachings] orally.

In this statement, the teacher and community chief Eunice Antunes contrasts two periods, separated by the invasion of the European colonizers and the introduction of the first schools among Guarani people. Please note that the demand for schooling by the Guarani communities themselves mentioned before in this text arose much later than the first period represented in Eunice's speech, from early colonial times. Within this first period, the legitimated knowledge institution was the House of Prayer. In the Opy, knowledge is conveyed through oral practices where social roles are those of the family sphere ("the grandfather, the uncle, the father") and the material activities are economic activities such as fishing and farming, organically linked to practices such as those of a spiritual nature ("all the religious matters, absolutely everything").

Eunice stresses how learning was practiced ("all learning was passed on orally but it was practiced"), contrasting this way of acquiring knowledge with the learning conveyed, since early colonial days, by the school, the knowledge institution originally alien to the community that was imposed as a universal human duty. Once introduced in Guarani communities, school, according to Eunice, took children out of the House of Prayer and made them "lose the teachings." Eunice relates this loss to the fact of children having started to "remain seated," undertaking a task alien to "their everyday life," namely, learning to read and write.

The introduction of schooling and literacy in colonial times, according to Eunice's words, was not appropriate to the social practices of the Guarani communities ("the child was no longer learning what needed to be learned"). However, the violence of the imposition of those universal human duties led to the radical transformation of Guarani forms of utterance and practices of generation and transmission of knowledge, thus impeding their current validity ("today [...] here it's impossible to pass on [teachings] orally"). 
Another transformation that resulted from the presence of school in the Guarani universe, pointed out by the collaborators of the research, is the transfer of the responsibility for the children's education to social roles different from solely family ones. This displacement was accentuated after the (re)introduction of schools in the villages at the request of the communities. Nevertheless, the school is not the only entity responsible for these transformations. The teachers of Itaty School also represented certain consumer goods (whose purchase by the Indians Townsend related to learning to read and write) as responsible for the transformation and delegitimization of oral forms of utterance and oral discursive practices. The following are Adão Antunes's words on this issue:

A gente notou assim [...] quem sabe não seja por causa da escola também, que já não tá quase mais existindo as histórias na oralidade, portanto... que os pais tão... estão soltando os filhos pros professores ensinar [...] o pai tá deixando de passar os ensinamentos oralmente pras crianças, contar história, contar os mitos... [...] Os alunos [...] não tão mais procurando o pai pra perguntar as coisas, eles matam todo o tempo dele na frente da televisão ou ouvindo música direto, mp3 [...] hoje mesmo os próprios pais em vez de sentar ao redor do fogo pra contar historia eles vão todos pra frente da televisão, pai, filho, tudo, a família toda vai pra frente da televisão assistir novela. (Interview with Adão Antunes, 01/11/2011)

We started noticing [...] and this might be also because of school, that there are almost no more stories being told orally, therefore ... the parents are ... handing their children over to the teachers to teach them [...] the father is giving up passing on teachings orally to the children, telling stories, telling the myths ... [...] students [...] don't chase their parents to ask about things, they just kill their whole time in front of TV or listening to music, non-stop, mp3 [...] today even the parents themselves, instead of sitting around the bonfire to tell stories, they all sit in front of TV to watch soap operas.

In this quote, it is possible to identify the shift between the social roles responsible for the education of children ("the parents are ... handing their children over to the teachers to teach them") which is making parents feel exempt from "passing on teachings orally to the children." Teacher Adão establishes a link between this displacement (and the children's inattentiveness to their parents' teaching) to the intense (and harmful, as implied by Seu Adão's lexical choices) relationship they have with some consumer goods ("they just kill their whole time in front of TV or listening to music, non-stop, mp3"). This relationship accelerates the progressive transformation, within the family environment, of the knowledge practices performed through oral forms of utterance as much as it transforms the discourses conveyed by them ("instead of sitting around the fire to tell stories, they all sit in front of TV to watch soap operas").

Assuming, with Chouliaraki and Fairclough (1999), the overdetermination between the discursive and nondiscursive elements of social practices, it is possible to affirm that transformations in the forms of utterance lead to transformations in the material activities, social relations, and values, beliefs, and desires that pattern 
the interactions of groups and individuals in social life. The next utterance by teacher Joana illustrates this point:

A tecnologia, ela vem afetando muito o povo indígena guarani principalmente, e tira totalmente da... em vez das crianças estarem brincando, irem pro mato, elas tão em casa, ouvindo música, estão na frente da televisão, eles querem videogame, eles querem jogos. (Interview with Joana Mongelo, 09/11/2011)

Technology has been transforming to a great extent Guarani people mainly, it pulls the kids out ... instead of them playing, going into the forest, they stay home listening to music, sitting in front of TV, they want videogames, they want games.

Those consumer goods identified with technology modify the forms of utterance and, with them, the material activities in which speakers get involved ("instead of them playing, going to the forest, they stay home"), as well as their beliefs, values, and desires ("they want videogames, they want games"). In this sense, for example, according to the teachers' speech, newer generations are paying less attention to the teachings of those that many recognize as the quintessential Guarani libraries, the elders. According to teacher João Batista, "depois que entrou a escola na aldeia, ai já muito poucos que ouvem, os jovens quase não ouvem mais os mais velhos" ('Since school came into the village, there are very few youths that listen to them, youths almost don't listen to the elders anymore.' Interview with João Batista Gonçalves, $01 / 11 / 2011$ ). From this utterance, it is possible to say that the transformation of forms of utterance induces the transformation of the knowledge practices regarded as legitimate. It triggers, furthermore, the transformation of the epistemology and the ways of generating knowledge that are congruent with the social purview of the group to which one belongs.

Teacher João Batista's words show the participants' worry over the loss of the elders' knowledge. They also show their worry over the role school and literacy play as tools for the relief of such an adverse condition:

Tem que deixar tudo escrito na escola porque culturalmente não existe mais os mais antigos também, e acaba esquecendo da língua, ai vai saber só as novas línguas também, ai já não vai ter mais a língua antiga, tem que ter tudo registrado [...] se não deixar registrado vai esquecer de como era a língua antiga também. (Interview with João Batista Gonçalves, 01/11/2011)

Everything has to be written at school because culturally the elders do not exist anymore either and, therefore, it's easier to forget the language and speak only the new languages, and so there will not be old language any more, everything must be recorded [...] if we don't leave everything on record, people are going to forget the way the old language was.

For teacher João Batista, writing has to play an essential role ("everything has to be written at school", "everything must be recorded") in the schoolwork to prevent the "old language" from falling into oblivion. The written register of the elders' knowledge and cultural tradition is considered by the Guarani to be a tool for 
preserving that knowledge. It is because of this that the signs record and register have become recurrent in the speech of Guarani teachers when talking about school literacy:

Esse registro vai ficar guardado, pra sempre também, quando os novos alunos, novas crianças que virão pra estudar, eles já vão diretamente nesse material "ô, tá aqui registrado: nossa história, conhecimento guarani, tá aqui registrado". (Interview with Marcos Morreira, 31/10/2011)

This record will be kept forever, when new students, new kids come to study they will go directly to that material: "Look, it's recorded here: Our history, Guarani knowledge, it is recorded here."

The transformation of the forms of utterance regarded as legitimate enough to be considered knowledge practices, over a change from oral practices toward literate practices, is represented in teacher Marcos's speech as definitive in the future. From his point of view, newer generations will resort to this written record of the tradition and not to its oral sources ("they will go directly to that material").

By way of summary, teacher Eunice Antunes's words below synthesize the relationship pointed out by the Guarani teachers between the forms of utterance linked to the generation and transmission of knowledge and the community's foundations of material life. Her words also represent the role school is to play in the reconstruction of this relationship:

Hoje aqui no Morro dos Cavalos principalmente que a gente [...] tá muito em contato com as coisas de fora, e ai a tecnologia também tá matando muito a cultura e ai as crianças já não... Aqui não tem um Karai, um rezador que vá todo dia na Casa de Reza [...] não tem um rio próximo pra eles tar pescando, caça, não tem como, agricultura, piorou [...] então pra as crianças aqui do Morro dos Cavalos crescer aprendendo a tradição é difícil [...] ai a escola aqui eu acho importante porque [...] nós como professores temos a obrigação de passar a parte cultural, que é a questão da religião, da tradição, nem que seja no papel [...] eu acho que se não tivesse escola a cultura hoje ia se perder. (Interview with Eunice Antunes, 07/11/2011)

Today, here in Morro dos Cavalos [...] we are in such close contact with the things from outside, and technology is killing our culture so much that children here no longer ... Here there is not a karai, a shaman that goes every day to the House of Prayer [...] there is not a river around for them to go fishing, hunting, no way, farming, even worse [...] so for children here in Morro dos Cavalos to grow up learning their tradition is very difficult [...] and therefore I find school here important because [...] as teachers we have the duty to pass on the cultural part, which includes religion, tradition, even though it is on paper ... [...] I think that if we had no school, our culture today would disappear.

These words point out the link between tradition, learning, and the foundations of material life. Eunice makes reference to the impossibility of carrying out some economic practices ("there is not a river around for them to go fishing, hunting, no 
way, farming, even worse"), to the lack of spiritual leaders that gather villagers in the House of Prayer, and to the resulting difficulty of learning their tradition ("for children here in Morro dos Cavalos to grow up learning their tradition is very difficult").

To overcome this difficulty, school and literacy are reconstructed by Guarani people as intercultural rights, as tools to reorient and reinterpret the transformation of forms of utterance and knowledge practices regarded as legitimate. Within this conjuncture, literate practices are regarded as the lesser of evils, ones that can assist in maintaining continuity in the transmission of Guarani traditional knowledge ("as teachers we have the duty to pass on the cultural part, which includes religion, tradition, even though it is on paper"). Literacy is an inevitable and indispensable lesser evil for the maintenance of tradition, which is a concept quite often bound up, in the discourses of the collaborator teachers, with the concept of culture ("the cultural part, which includes religion, tradition," "I think that if we had no school, our culture today would disappear").

At this point, it is necessary to highlight how recurrent the references are to culture and knowledge as static objects and as synonyms for tradition in the speech of all the research collaborators. They are used to referring to sociocultural practices of an idealized past time, the old days. It is this perspective that supports discourses about culture and knowledge as objects that can disappear and be killed ("technology is killing our culture so much," "I think that if we had no school, our culture today would disappear"), and thus, as something that can be written and recorded ("Everything has to be written at school because culturally the elders do not exist anymore," "Our history, Guarani knowledge, is recorded here").

Such discourses can be resignified upon a dynamic notion of culture, such as that of Geertz (1973) or Heath and Street (2008). As mentioned earlier in this text, these authors defend a semiotic notion of culture, linked either to webs of significance (Geertz, 1973) or metanarratives (Heath \& Street, 2008) through which social groups make sense of their particular history, habits, and behaviors. Heath and Street (2008) emphasize the dynamism of culture in their argument in favor of an understanding of the sign culture as a verb, due to its infinite and kaleidoscopic power of transformation, rather than as a noun, in order to avoid the static nature denoted by that grammatical category.

It is this semiotic notion of culture, nonetheless, that underlies the Guarani appropriation of universal human duties such as schooling and literacy, as well as their reconstruction as intercultural human rights. It is due to the dynamic nature of culture that the Guarani appropriate those duties, reinterpreting them and locating them within their social purview as weapons they need for resistance and survival because of the harassment of the Non-Indigenous world and the capitalist political and economic system. Those intercultural rights enable, to some extent, the reorientation of the transformations of the knowledge practices and forms of utterance that are threatening the transmission of knowledge and the epistemological bases of the Guarani tradition. Writing represents an indispensable instrument within this strategy of resistance: 
A questão da escrita guarani, das historias guarani [...] a gente usa como uma arma também de defesa, de sobrevivência [...] E ai então a gente usa como... uma estratégia [...] tu aprende a falar em português pra me defender, tu aprende a escrever alguma coisa pra me defender, então é tudo defesa mesmo, divulgar a minha cultura pra que a pessoa que conheça a minha cultura ele me respeite do jeito que eu sou assim como eu tô respeitando ele. (Interview with Eunice Antunes, 07/11/2011)

The matter of Guarani writing, of Guarani stories [...] we use it also as a weapon for defense, for survival [...] we use it ... as a strategy [...] you learn to speak Portuguese for defense, you learn to write something for defense, so everything is indeed defense, everything aims at spreading my culture for the person that gets to know my culture to treat me as respectfully as I am treating him.

Teacher Eunice's speech does not represent "the matter of Guarani writing" either as a civilizing good or as an inherently positive evolutionary breakthrough. On the contrary, she represents it as a weapon for defense ("everything is indeed defense") before the transformation that the hierarchical organization of social relations exerts over the Guarani forms of utterance and discursive practices and, inextricably, over the foundations of their material life and their social relations, beliefs, values, and desires. It is upon this assertion that the concluding remarks are offered in the following section.

\section{Concluding Remarks}

The intercultural reconstruction of linguistic human rights at Itaty School enabled the emergence of meanings still plundered from the "intentional possibilities of language" that are exploited by "socially significant world views" (Bakhtin, 1981, p. 290), especially by those views that are identified with the metanarrative of modernity (Lander, 2005). In this metanarrative, the distinction between orality and literacy serves to categorize individuals in two distinctive cognitive classes, one of them primary and primitive, to be eradicated (the category of illiterates), and another identified with the essential needs of modern and developed individuals and societies (Galvão \& Batista, 2006). Thus, ever since the social heteroglossia and the clash of social value judgments occurring in the signs and discourses on literacy was concealed, literacy has been traditionally inserted in the social purview of the already monoglossic dominant groups, represented as an evolutionary process which is inherently good and is a universal right that must be granted to all human beings.

This silencing of discourses about literacy invisibilizes the meanings that it has for those communities that are traditionally regarded as illegitimate, such as the Guarani communities and all Indigenous communities alike. Literacy is inserted in these communities' social purview as a weapon for defense and survival which became necessary due to violent transformations in their forms of utteranceinextricably linked to transformations in their foundations of material life, social relations, beliefs, values, and desires. With this weapon, Guarani people seek to 
reorient the changes in their discursive universe and to keep struggling for a fuller sovereignty over their forms of utterance, inseparable from a fuller sovereignty over their economy.

\section{References}

APIB (National Articulation of the Indigenous People of Brazil). (2012). Letter of denunciation from the National Articulation of the Indigenous People of Brazil to United Nations (in Portuguese). Retrieved from http://blogapib.blogspot.com.br/2012/11/carta-da-apib-as-nacoes-unidassobre.html.

Bakhtin, M. (1981). The dialogic imagination. Austin: University of Texas Press.

Barros, M.C. D.M. (1994, Jul./Sep.). Educação bilíngue, linguística e missionários. Em Aberto (Brasília) 14(63), 18-37.

Brasil. (2010). Constitution of the Federal Republic of Brazil: Constitutional Text of October 5, 1988, with alterations introduced by Constitutional amendments no. 1/1992 through 64/2010 and by Revised Constitutional Amendments no. 1/1994 through 6/1994. 3rd ed. Brasília: Chamber of Deputies, Documentation and Information Center. Retrieved from http://www.stf.jus.br/repositorio/cms/portalStfInternacional/portalStfSobr eCorteen us/anexo/constituicao ingles 3ed2010.pdf

César, A.L., \& Cavalcanti, M.C. (2007). Do singular para o multifacetado: o conceito de língua como caleidoscópio. In M. C. Cavalcanti \& S. M. Bortoni-Ricardo (Eds), Transculturalidade, linguagem e educação (pp. 45-65). Campinas: Mercado de Letras.

Chouliaraki, L., \& Fairclough, N. (1999). Discourse in late modernity. Edinburgh: Edinburgh University Press.

CIMI (Missionary Indigenist Council). (2012). Report on Violence against Indigenous Peoples in Brazil (in Portuguese)._Retrieved from www.cimi.org.br/pub/viol/viol2012.pdf.

Franchetto, B. (2008). A guerra dos alfabetos: os povos indígenas na fronteira entre o oral e o escrito. Mana, 14(1), 31-59. Retrieved from http://www.scielo.br/pdf/mana/v14n1/a02v14n1.pdf.

Galvão, A. M., \& Batista, A. A. G. (2006). Oralidade e escrita: uma revisão. Cadernos de Pesquisa (Fundação Carlos Chagas, São Paulo), 36(128), 403-432. Retrieved from http://www.scielo.br/pdf/cp/v36n128/v36n128a07.

Gee, J. P. (1994). Social linguistics and literacies: Ideology in discourses. London: Routledge.

Geertz, C. (1973). The interpretation of cultures: Selected essays by Clifford Geertz. New York: Basic Books. 
Guarani Community of Morro dos Cavalos, Nhemonguetá Guarani Board, Indigenous Peoples State Council, Missionary Indigenist Council, Committee for Indigenous Issues/Brazilian Anthropology Association, MArquE, and Indigenous Undergraduate Program/UFSC. Chronology of the struggle for the demarcation of the Indigenous land of Morro dos Cavalos - relevant facts. Waiting for two decades (1993-2013). Retrieved from www.cimi.org.br/pub/viol/viol2012.pdf.

Guerola, C.M. (2012). "Às vezes tem pessoas que não querem nem ouvir, que não dão direito de falar pro indígena": a reconstrução intercultural dos direitos humanos linguísticos na escola Itaty da aldeia guarani no Morro dos Cavalos (Unpublished Master's thesis). Universidade Federal de Santa Catarina, Florianópolis, Brazil.

Heath, S.B., \& Street, B. (2008). On ethnography: Approaches to language and literacy research. New York: Teachers College Press.

Kleiman, A.B. (1995). Modelos de letramento e as práticas de alfabetização na escola. In A. B. Kleiman (Ed.), Os significados do letramento: uma nova perspectiva sobre a prática social da escrita (PP. 15-61). Campinas: Mercado de Letras.

Lander, E. (2005). Ciências sociais: saberes coloniais e eurocêntricos. In E. Lander (Ed.), A colonialidade do saber: eurocentrismo e ciências sociais. Perspectivas latino-americanas. Buenos Aires: CLACSO. Retrieved from http://bibliotecavirtual.clacso.org.ar/ar/libros/lander/pt/Lander.rtf.

Litaiff, A., \& Darella, M.D.P. (2000). Os índios guarani mbya e o parque estadual da Serra do Tabuleiro. Paper presented at the XXII Brazilian Anthropological Meetings, Brasília. 2000.

Meliá, B. (1979). Educação indígena e alfabetização. São Paulo: Loyola.

Mignolo, W.D. (2004). Os esplendores e as misérias da "ciência": colonialidade, geopolítica do conhecimento e pluri-diversidade epistémica. In B. Sousa Santos (Ed.), Conhecimento prudente para uma vida decente: um discurso sobre as ciências, revisitado (pp. 667-709). São Paulo: Cortez.

Sousa Santos, B. (2002). Toward a multicultural conception of human rights. In B. Hernandez-Truyol (Ed.), Moral imperialism: A critical anthology (pp. 39-60). New York: New York University Press.

Sousa Santos, B. (2010). Descolonizar el saber, reinventar el poder. Montevideo: Trilce.

Street, B. (2003). What's "new" in New Literacy Studies? Critical approaches to literacy in theory and practice. Current Issues in Comparative Education, 5(2), 1-14. Retrieved from http://devweb.tc.columbia.edu/i/a/document/25734 52 Street.pdf. 
Vieira, I. F. (2006). Educação escolar indígena: as vozes Guarani sobre a escola na aldeia. (Unpublished Master's thesis). Universidade Federal de Santa Catarina, Florianópolis, Brazil.

Voloshinov, V.N. (1986). Marxism and the philosophy of language. (L. Matejka \& I. R. Titunik, Trans.). Cambridge, MA: Harvard University Press. (Original work published 1929). 